\title{
Effects of Roasting and Boiling on the Yield, Quality and Oxidative Stability of Extracted Soya Bean Oil
}

\author{
Samuel Kofi Tulashie ${ }^{1 *}$, Francis Kotoka, Amponsah Preko Appiah ${ }^{1}$, Philip Awuah ${ }^{2}$, Bright K.A. \\ Baiden $^{3}$ \\ ${ }^{1}$ Industrial Chemistry Unit, Department of Chemistry, University of Cape Coast, Cape Coast, \\ Ghana.Email:stulashie@ucc.edu.gh \\ ${ }^{2}$ Ghana Nuts Company Limited, Techiman, Brong Ahafo Region, Ghana. \\ ${ }^{3}$ Chemical and Paper Engineering Department, Western Michigan University, Michigan, USA.
}

\section{ABSTRACT}

In this study, the effect of roasting and boiling on the yield and oxidative stability of soya bean oil was investigated. The oil was soxhlet extracted and the oxidative stability was determined by the free fatty acid value, acid value and peroxide value. The results showed that the oil yield, free fatty acid value, acid value and peroxide value were significantly affected by roasting, boiling, and the thermal treatment time. The percentage oil yield in the control oil sample was $18.51 \%$, which increased to $20.24 \%$ and $20.73 \%$ after boiling and roasting respectively, at $40 \mathrm{mins}$. The corresponding free fatty acid and the peroxide value of the control oil sample were $0.14 \%$ and $2.04 \mathrm{meqO} / \mathrm{kg}$, which increased to $0.82 \%$ and $6.60 \mathrm{meqO}_{2} / \mathrm{kg}$ by roasting, and $0.47 \%$ and $5.62 \mathrm{meqO}_{2} / \mathrm{kg}$ by boiling respectively. Thus the oil yield, free fatty acid value, peroxide value, and acid value increased with increasing roasting and boiling time.

The results indicate that roasting provides a higher oil yield than boiling, but boiled oil has higher oxidative stability than roasted oil.

Keywords: Roasting; Boiling; Soya bean; Oil Extraction; Oxidative stability.

\section{Introduction}

Oils obtained from oilseeds provide the calories, vitamins and essential fatty acids in the human diet in an easily digested form. The rate of vegetable oil consumption is increasing compared with animal fat due to its low sterol [1]. The largest sources of vegetable oil are annual plants, which include soybean (Figure 1), corn, cottonseed, groundnut, sunflower, rapeseed, melon and sesame seed ${ }^{[2]}$. Other sources are oil bearing perennial plants such as olive, coconut, shea,cashew and palm.

Separation of oil from oil seeds is an important processing operation. The process employed has a direct effect on the quality and quantity of oil obtained from the oil seeds ${ }^{[4]}$. There are three (3) major methods used in the extraction of oil from various agricultural seeds. These are the mechanical/hydraulic pressing method, solvent extraction method and rendering method ${ }^{[5]}$. Soybean oil as shown in Figure 2 is extracted from the seeds either by a solvent, mechanical pressing or aqueous enzymatic extraction. However, the common processing methods used to prepare the oilseeds for human consumption are roasting and boiling, followed by solvent extraction.

Roasting refers to the use of heat treatment to induce the development of the typical colour, taste and flavor. It alsochanges the chemical composition, modifying nutritional value and shelf life ${ }^{[7]}$, therefore, roasting is considered as the key step in making condiment oil ${ }^{[8]}$. Similarly, boiling is one of the commonest processing methods used to prepare oilseeds and also the most difficult process due to the difficulty in removing any traces of water that were used for boiling.It also affects the moisture content of the seed which in turn affects the extraction process. The solvent extraction method involves the leaching out of the insoluble solid structure of the oil seeds by the use of volatile organic solvent, e.g. $\mathrm{n}$-Hexane Isopropanol, Buthanol, and Acetane ${ }^{[9]}$. Solvent extraction is the most widely used oil-recovery method for soybeans, but it also requires considerable capital and large scale to compete.

Copyright (C) 2018 Samuel Kofi Tulashie et al.

doi: $10.24294 /$ tse.v1i2.424

EnPress Publisher LLC.This work is licensed under the Creative Commons Attribution-NonCommercial 4.0 International License (CC BY-NC 4.0). $\mathrm{http} / / /$ creativecommons.org/licenses/ by/4.0/ 


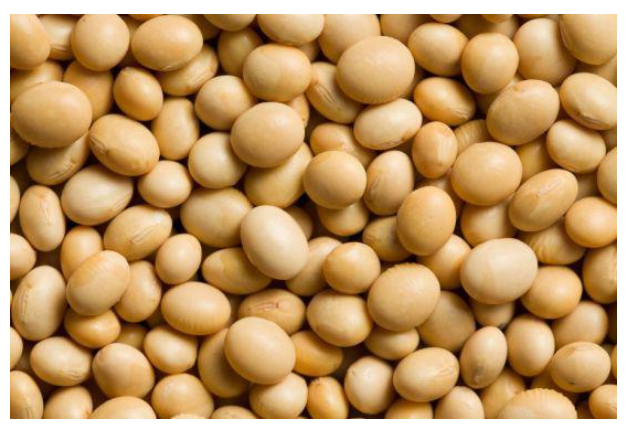

Figure 1; Soya bean seeds. ${ }^{[3]}$

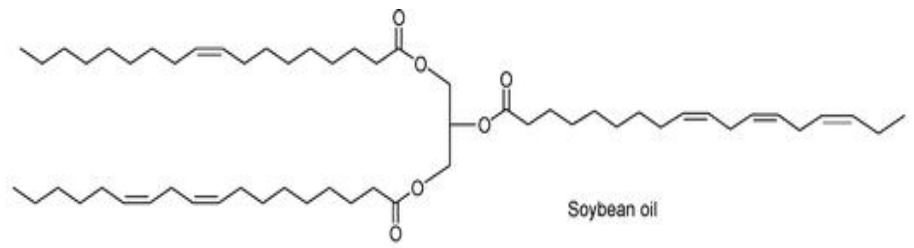

Figure 2; Structure of Soya bean $\mathrm{Oil}^{[6]}$

Several studies have been done on extraction of vegetable oils as well as the effects of moisture content, heating temperature, and heating time on oil yield and oil oxidative stability. For instance, it was reported that the oil yield from castor beans at any pressure was dependent on the moisture content, with higher yield obtained at 8-10\% moisture content after heating ${ }^{[10]}$. It was also reported that the total amount of oil extracted from jatropha kernels, and other vegetable oils depended mainly on the extraction time and temperature, moisture content and particle size of the oil bearing material, with the oil extracted during the first 20 minutes of extraction ${ }^{[1,11]}$. Conversely, the effects of roasting and boiling on oil yield and stability had also been investigated. Roasting and boiling processes were reported to have increased oil yield but changed the chemical composition, amino acid and oxidative stability of the oil from soya bean seeds, safflower seeds, orange seeds, and coconut ${ }^{[12,13]}$. Furthermore, the oxidative stability, peroxide value, and acid value of soya bean oil had been stated to have increased via roasting and boiling ${ }^{[8,14,15]}$.

Indeed, several studies have been done on soya bean oil extraction but little exploration had been done on the effects of boiling and roasting on the oil yield, and oxidative stability. This present study investigated the effects of roasting and boiling on the yield, quality, and oxidative stability of extracted soya bean oil.

\section{Materials and Methods}

\subsection{Chemicals and reagents}

$0.1 \mathrm{~N}$ sodium hydroxide solution, phenolphthalein indicator solution, acetic acid isooctane, potassium iodide, 0.01 $\mathrm{N}$ sodium thiosulfate, ethanol and $\mathrm{n}$-hexane were obtained from Ghana Nut Company Limited laboratory. All other chemicals used were of analytical grade and were obtained from standard chemical suppliers.

\subsection{Sample collection}

Soybeans samples were purchased from a local market in Techiman in the Brong Ahafo region of Ghana.

\subsection{Thermal treatment of samples}

The soybean seeds were first cleaned of dirt and foreign particles such as sand, stones, wood and metal particles. The samples were then rid of insects by sun drying for three days, after which they were then sorted and divided into two equal portions for the thermal treatment processes. The first portion of the Soybean samples was boiled whereas the other portion was roasted; all in a stainless steel container on a hot plate at $100{ }^{\circ} \mathrm{C}$ for 20 mins and 40 mins respectively. The samples were cooled, dried and ground into fine powder using an electric blender and then stored in clean containers in a fridge.

\subsection{Determination of Moisture and Volatile Matter}

An empty dish was dried and weighed and the mass was recorded as $\mathrm{W}_{1} .10 \mathrm{~g}$ of the sample was placed into the dish and the new weight was recorded as $\mathrm{W}_{2}$. It was then brought to drying in a preheated oven set at $105 \pm 1^{\circ} \mathrm{C}$ for $3 \mathrm{hrs}$. The sample was removed and cooled in desiccators for $30 \mathrm{mins}$. It was then weighed and record final weight as $\mathrm{W}_{3}$. The procedure was repeated for all the treatments.

$\%$ Moisture and volatile matter $=\frac{w_{3}-w_{1}}{w_{2}-w_{1}} \times \mathbf{1 0 0}$

Where, $\mathrm{W}_{1}=$ Weight of empty dish

$$
\begin{aligned}
& \mathrm{W}_{2}=\text { Weight of dish }+ \text { sample } \\
& \mathrm{W}_{3}=\text { Weight dried sample }
\end{aligned}
$$




\subsection{Oil Extraction Using Soxhlet Method}

Oil extraction was done using the Soxhlet method with n-hexane as solvent, and the oil yield in the initial sample was then calculated as follows:

$$
\% \text { oil yield }=\frac{w_{0}}{w} \times 100
$$

Where

$\mathrm{W}_{0}=$ weight of oil extracted

$\mathrm{W}=$ weight of the sample

\subsection{Determination of Free Fatty Acid}

$50 \mathrm{ml}$ of hot, neutral ethanol and a few drops of phenolphthalein were added to $5 \mathrm{~g}$ of the oil sample in Erlenmeyer flask, and shaken vigorously. The resulting solution was titrated with $0.1 \mathrm{~N} \mathrm{NaOH}_{(\mathrm{aq})}$ with constant shaking until the pink colour remained constant. From the quantity of $0.1 \mathrm{~N} \mathrm{NaOH}_{(\mathrm{aq})}$ used, the percent free acid was calculated shown in equation (3), stating the result in terms of oleic acid ${ }^{[16]}$.

Where $\mathrm{V}=$ Volume in $\mathrm{ml}$ sodium hydroxide used

$$
\text { Free fatty acids as oleic acid }=\frac{2 \mathrm{n} .2 \times \mathrm{V} \times \mathrm{N}}{\mathrm{w}}
$$

$\mathrm{N}=$ Normality of the Sodium hydroxide solution; and

$\mathrm{W}=$ Weight in $\mathrm{g}$ of the sample

\subsubsection{Determination of Acid value}

$50 \mathrm{ml}$ freshly neutralized hot ethanol and one drop of phenolphthalein indicator solution were added to $5 \mathrm{~g}$ of the cooled soybean oil in a $250 \mathrm{ml}$ Erlenmeyer flask. The resulting hot mixture was boiled for about $5 \mathrm{mins}$ and titrated against standard alkali solution, shaking vigorously during the titration until the pink colour remained constant. The acid value was calculated as follows:

$$
\Lambda \text { cid value }=\frac{3 i .1 \times V \times x}{W}
$$

Where $\mathrm{V}=$ Volume in $\mathrm{ml}$ sodium hydroxide used

$\mathrm{N}=$ Normality of the $\mathrm{NaOH}_{(\mathrm{aq})}$; and

$\mathrm{W}=$ Weight in $\mathrm{g}$ of the sample

\subsection{Determination of Peroxide value}

$30 \mathrm{ml}$ of the acetic acid-isooctane solution (3:2) was added to $5 \mathrm{~g}$ of the sample in a $250 \mathrm{ml}$ Erlenmeyer flask, follow by swirling to dissolve the oil. $0.5 \mathrm{ml}$ of the saturated $\mathrm{KI}_{(\mathrm{aq})}$ was then added and allowed to stand with occasional shaking for $1 \mathrm{~min}$, follow by the addition of $30 \mathrm{ml}$ of distilled water. The solution was slowly titrated with $0.01 \mathrm{~N}$ $\mathrm{Na}_{2} \mathrm{~S}_{2} \mathrm{O}_{3}$ (sodium thiosulfate) with vigorous shaking until the yellow color was almost disappeared. As the titration continued, $0.5 \mathrm{ml}$ of starch was added while shaking vigorously to release all the iodine from the isooctane layer, until the blue color disappeared. The peroxide value was calculated as shown in equation (5)

$$
\text { Peroxide value }=\frac{s-\Delta \times N \times 1000}{W}
$$

Where

$\mathrm{S}=$ volume of $\mathrm{Na}_{2} \mathrm{~S}_{2} \mathrm{O}_{3}$ used for sampling

$\mathrm{B}=$ volume of $\mathrm{Na}_{2} \mathrm{~S}_{2} \mathrm{O}_{3}$ used for blank

$\mathrm{N}=$ normality $\mathrm{Na}_{2} \mathrm{~S}_{2} \mathrm{O}_{3}$

$\mathrm{W}=$ weight of the sample $(\mathrm{g})$

\subsection{Statistical analysis}

All measurements were in triplicates and the results presented as a mean value \pm standard deviation (SD) were analyzed using statistical package for social science (SPSS) research version 16. Statistically significant difference between roasting and boiling times were calculated at the level of confidence $\alpha=0.05$. In order to find out if the difference in the mean values estimated were statistically significant, the one -way analysis of variance was applied.

\section{Results and Discussions}




\subsection{Percentage Moisture Content}

Table 1 indicates the moisture content of the raw, boiled, and roasted soya beans. The raw beans moisture content determined to be $4.92 \%$. It was observed that the beans roasted for 40 mins exhibited the lowest moisture content of $2.04 \%$, followed by the roasted soya beans for $20 \mathrm{mins}$ with a moisture content of $3.99 \%$. The boiled beans at $40 \mathrm{mins}$ obtained the highest moisture content of $7.22 \%$, followed by those boiled at $20 \mathrm{mins}(6.47 \%)$.

\begin{tabular}{ll}
\hline \multicolumn{1}{c}{ Samples } & \%Moisture Content \\
\hline Raw Beans & 4.92 \\
Roasted Beans /20mins & 3.99 \\
Boiled Beans /20mins & 6.47 \\
Roasted Beans /40mins & 2.04 \\
Boiled Beans /40mins & 7.22 \\
\hline
\end{tabular}

Table 1.Percentage Moisture content of the roasted and boiled soya beans

Thus, the moisture content in the roasted beans at 40 mins and 20 mins was reduced by $2.89 \%$ and $0.93 \%$, respectively, while that of the boiled beans was increased by $2.3 \%$ and $1.55 \%$ at 40 mins, and 20 mins, respectively. The differences in moisture content of the two thermal treatments processes may be as a result of water absorption, and evaporation during boiling, and roasting respectively. The result is consistent with other literatures that reported that boiled beans have higher moisture content than roasted beans ${ }^{[1,17]}$.

\subsection{Effect of roasting on oil yield and stability of oil}

The oxidative stability of the oil was determined by investigating the effects of roasting time on the free fatty acid, peroxide value and acid value as these properties are strong indicators of the stability of the oil. Table 2 depicts the effects of roasting on oil yield and oxidative stability of the soya bean oil.

\begin{tabular}{lccccc}
\hline Treatment & Time/mins & \%Fat/oil & \%FFA & PV meO $/ \mathbf{k g}$ & AVmg/NAOH/g \\
\hline Raw & 0 & $18.51 \pm 0.500^{\mathrm{a}}$ & $0.14 \pm 0.0577^{\mathrm{a}}$ & $2.04 \pm 0.1012^{\mathrm{a}}$ & $0.27 \pm 0.1732^{\mathrm{a}}$ \\
& & & & & \\
Roasting & 20 & $19.72 \pm 0.500^{\mathrm{b}}$ & $0.54 \pm 0.0361^{\mathrm{c}}$ & $3.37 \pm 0.2080^{\mathrm{b}}$ & $1.05 \pm 0.0723^{\mathrm{b}}$ \\
& & & & & $1.60 \pm 0.0665^{\mathrm{ab}}$ \\
\hline
\end{tabular}

Table 2. Effects of roasting on oil yield and chemical properties of the soya beans

Values are means \pm standard deviation of the means of three measurements. Values followed by the same superscript in a column indicates significant difference between these values at a $\mathrm{p}<0.05$.

The fat content/oil content, free fatty acid, peroxide value and the acid value of the raw bean sample at time zero $(0$ $\mathrm{min}$ ) were determined to be $18.51 \pm 0.500 \%, 0.14 \pm 0.0577 \%, 2.04 \pm 0.1012 \mathrm{meO}_{2} / \mathrm{kg}$, and $0.27 \pm 0.1732 \mathrm{mg} / \mathrm{NAOH} / \mathrm{g}$, respectively. It was observed that all these determined properties increased with the roasting time. At 20 mins of roasting, the fat content, free fatty acid, peroxide value, and the acid value increased to $19.72 \pm 0.500 \%, 0.54 \pm$ $0.0361 \%, 3.37 \pm 0.2080 \mathrm{meO}_{2} / \mathrm{kg}$, and $1.05 \pm 0.0723 \mathrm{mg} / \mathrm{NAOH} / \mathrm{g}$ respectively. They respectively increased further to $20.73 \pm 0.255 \%, 0.82 \pm 0.0305 \%, 6.60 \pm 0.0416 \mathrm{meO}_{2} / \mathrm{kg}$, and $1.60 \pm 0.0665 \mathrm{mg} / \mathrm{NAOH} / \mathrm{g}$ at 40 mins. The increment in the aforementioned properties during roasting may be due to the breaking down of the oil cells and cell walls, protein 
coagulation, moisture content adjustment, increase in hydrolysis of the oil cells, which enhanced the movement of the fats and other compounds from the cells to the ambience. The results obtained is similar to other studies which reported increment in fats/oil content and other compounds during roasting ${ }^{[1]}$

\subsection{Effect of boiling on oil yield and stability of oil}

The effects of boiling on oil yield and oxidative stability of oil of soybeans was also investigated. As shown in Table 3, there was consistent increment in the oil yield and all the other investigated properties with increasing boiling time.

\begin{tabular}{lccccc}
\hline Treatment & Time/mins & \% fat & \% FFA & PV/meO $/ \mathbf{k g}$ & AVmg/NAOH/g \\
\hline Raw & 0 & $18.51 \pm 0.0500^{\mathrm{a}}$ & $0.14 \pm 0.0057^{\mathrm{a}}$ & $2.04 \pm 0.1012^{\mathrm{a}}$ & $0.27 \pm 0.1732^{\mathrm{b}}$ \\
& 20 & $19.36 \pm 0.0550^{\mathrm{c}}$ & $0.43 \pm 0.0577^{\mathrm{b}}$ & $2.77 \pm 0.1528^{\mathrm{b}}$ & $0.83 \pm 0.0577^{\mathrm{a}}$ \\
Boiling & 40 & $20.24 \pm 0.0800^{\mathrm{b}}$ & $0.47 \pm 0.0361^{\mathrm{b}}$ & $5.62 \pm 0.1442^{\mathrm{ab}}$ & $0.92 \pm 0.5568^{\mathrm{a}}$ \\
& & & & & \\
\hline
\end{tabular}

Table 3. Effects of boiling on oil yield and chemical properties of the soya beans

Values are means \pm standard deviation of the means of three measurements. Values followed by the same superscript in a column indicates significant difference between these values at a $\mathrm{p}<0.05$.

The highest properties were recorded at 40 mins of boiling. Thus, the fat content, free fatty acid, peroxide value, and acid value increased correspondently from $18.51 \pm 0.500 \%, 0.14 \pm 0.0577 \%, 2.04 \pm 0.1012 \mathrm{meO} / \mathrm{kg}$, and $0.27 \pm 0.1732 \mathrm{mg} / \mathrm{NAOH} / \mathrm{g}$ to $20.24 \pm 0.0800 \%, 0.47 \pm 0.0361 \%, 5.62 \pm 0.1442 \mathrm{meO} / \mathrm{kg}$, and $0.92 \pm 0.5568$ $\mathrm{mg} / \mathrm{NAOH} / \mathrm{g}$. Like roasting, the increment in the investigated properties may also be due the breaking down of the oil cells and cell walls, protein coagulation, moisture content adjustment, increase in hydrolysis of the oil cells The overall effects of the oil yield, free fatty acid, peroxide value, and acid value of the soya beans are clearly depicted in Figure 3. The results indicate a remarkable influence of roasting and boiling soya beans oil and its properties. Heating of oil broke down the oil cells, coagulated protein and adjusted the moisture content of meal to optimize value for extraction whiles reducing oil viscosity. All these effects allowed easy extraction of the oil. As the temperature increased, the hydrolysis of the oil cells also increased.

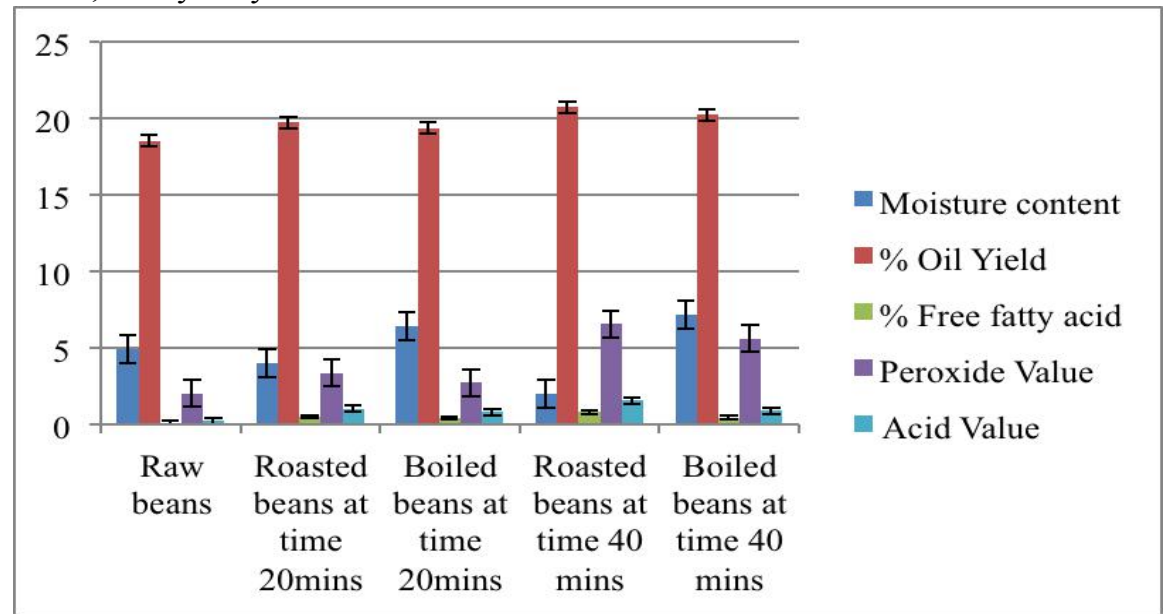

Figure 3; The effects of roasting and boiling on the moisture content, oil yield, free fatty acid, peroxide value, and acid value ofthe soya beans with respect to time.

It was observed that except the moisture content, the roasting process produced higher values of the investigated properties than boiling throughout the treatment period. Both treatments led to significant difference $(p<0.05)$ in the oil 
content. The results showed that the oil content of the soya bean seeds obtained via roasting, and boiling at 40 mins increased from $18.51 \%$ in raw samples to more than $20.00 \%$. However, at 40 mins, the highest oil yield was obtained via roasting $(2.22 \%)$ than boiling $(1.73 \%$ increment). This implies that oil yield increases with time, and roasting produces higher oil yield than boiling. These results are similar to other literature which reported oil yield with roasting and boiling time ${ }^{[12]}$.

It was also observed that the investigated properties increased in both thermal treatments. However, the roasting process increased the free fatty acid, the peroxide value, and the acid value appreciably than the boiling process. There were significant changes in free fatty acid value, and the acid value during boiling and roasting ( $p<0.05$ ). However, there were no significant difference between the 20 mins and 40 mins of boiling though roasting exhibited significant difference between the 0,20 and 40 mins. The results, therefore, suggest that since the free fatty acid value and peroxide value respectively measures the extent to which the glycerides in the oil have been decomposed by lipase action, and gives the initial evidence of rancidity in unsaturated oils, both the boiling and roasting processes may enhance the hydrolytic rancidity of the soy bean oil, hence, affecting the oxidative stability of the oil. However, the results generally showed that oil extracted from roasted soya beans seed at $100^{\circ} \mathrm{C}$ had greater oil yield but relatively lower oxidative stability, hence, may have a reduced shelf life than oil extracted from boiled soya beans. The results are consistent with other studies which indicated that roasted soya bean oil has higher yield but lower oxidative stability ${ }^{[15,16,18,19]}$.

\section{Conclusion}

The results obtained in the present work have showed the yield, roasting and boiling processes affected quality and oxidative stability of extracted soya bean oil. Thus; roasting is preferred when higher yield is required but may however decrease the quality and shelf life of the oil as it produced higher free fatty acid value, acid value and peroxide value which significantly account for the oxidative rancidity and consequently affects the oils oxidative stability. Boiling as a heat treatment on the other hand may not give higher yields as expected, but may increase the quality and shelf life of the soya bean oil produced. However, the results indicate that boiling can potentially induce oxidative rancidity since the acid values, peroxide values, and free fatty acid values were also appreciable.

It is therefore recommended that further studies be carried out on the optimization of these heat treatment techniques or better still develop a new treatment method that will not only ensure a high oil yield but will also significantly improve the oil quality, oxidative stability and shelf life generally.

\section{Conflict of interest}

The authors have no conflicts of interest regarding the publication of this paper.

\section{Acknowledgement}

We thank the University of Cape Coast-Ghana and Ghana Nut Company Limited for their laboratory assistance.

\section{References}

1. Akinoso R, Igbeka JC, Olayanju TMA and Bankole LK. Modelling of oil expression from palm kernel (Elaeis guineensis Jacq). Agricultural Engineering International - the CIGR Ejournal 2006;( 8): 1-8.

2. O’Brien R.D. Fats and oils formulating and processing for application. USA: Inc Lancaster, 2008; 245

3. Soya bean seeds. Avalable at https://www.organicfacts.net/wp-content/uploads/2013/06/Soyabean.jpg/ (Accessed 16/12/2016)

4. Bargale PC. Mechanical oil expression from Selected Oilseeds under Uniaxial Compression. Ph.D thesis, Canada: University of Saskatechewan 1997.

5. Liauw MY, Natan FA, Widiyanti $\mathrm{P}$, et al. Extraction of Neem oil(Azachirachta indica A. Juss) using n-hexane and ethanol:studies on oil quality, kinetic and thermodynamic. ARPN Journal of Engineering and Applied Sciences 2008; 3(3): 49-54.

6. Biswas A, Sharma BK, Willett JL, et al. Soybean oil as a renewable feedstock for nitrogen-containing derivatives. Energy Environ. Sci. 2008; 1(6): 639-644.

7. Ozdemir M, Yusuf D. Analysis of color development during roasting of hazelnuts using response surface methodology. Journal of Food Engineering 2000; 45(1): 17-24

8. Lee YC, Kim IH, Chang J, et al. Chemical Composition and Oxidative Stability of Safflower Oil Prepared with Expeller from Safflower Seeds Roasted at Different Temperatures. Food Chemistry 2004; 69 (1):1-6 
9. Obikili CM. Evaluation Of The Effect of Methods of Oil Extraction On Physico-Chemical Properties of Oil From African Breadfruit Seeds, (Treculia africana) And Cashew Nuts (Anarcardium Occidentale) Unpublished Undergraduate Project. Department Of Agricultural And Bioresources Engineering, Federal University Of Technology, Minna, Niger State 2010; 12-18.

10. Oluwaniyi OO, Dosumu OO, Awolola GV. Effect of local processing methods (boiling, frying and roasting) on the amino acid composition of four marine fishes commonly consumed in Nigeria. Food Chemistry 2010; 123: 1000-1006.

11. Sirisomboon P, Kitchaiya P. Physical Properties of Jatropha Curcus L. Kernels after Heat Treatments. Journal of Biosystem Engineering 2008; 102: 244-25.

12. Mariod AA, Ahmed SY, Abdelwahab SI, et al. Effect of roasting and boiling on the chemical composition, amino acids and oil stability of safflower seeds. International Journal Of Food Science And Technology 2012;47(8): 1737-1743

13. Akpan EJ, Etim OE, Akpan HD, et al. Fatty acid profile and oil yield in different varieties of fresh and dried samples of coconut (cocus nusifera).Pak. J.Nut. 2006; 5: 106 -109.

14. Farag RS, Hewedi FM, Abu-Raiia SH, et al. Comparative study on the deterioration of oils by microwave and conventional heating. J. Food Port. 1992; 55:722-727.

15. Yoshida H, Hirooka N, Kajimoto G. Microwave energy effects on quality of some seed oils, J. Food Sci. 1990; 55: 1412-1416.

16. Farooq A, Syeda NZ, Umer R. Characterization of Moringa Oleifera Seed Oil From Drought and Irrigated Regions of Punjab, Pakistan. Department of Chemistry,University of Agriculture, Faisalabad-38040, Pakistan 2006; 57(20):160-168.

17. Adegoke GO, Falade KO, Babalola OC. Control of lipid oxidation and fungal spoilage of roasted peanut (Arachis hypogaea) using the spice Aframomum danielli. Journal of Food Agriculture and Environment 2004; 2: 128-131

18. Megahed MG. Microwave roasting of peanuts. Effects on oil characteristics and Composition. Nahrung 2001; 45: 225-257

19. Buckholz, Daun JH, Stier E, Trout R. Influence of roasting time on sensory attributes of fresh roasted peanuts. J. Food Sci. 1980; 45: 547-554 